\title{
THE IMPACT OF AN ACCENT: THE EXPERIENCES OF INTERNATIONAL COLLEGE STUDENTS FROM INDIA IN THE GREATER TORONTO AREA
}

by

Micheline Chevrier, B.A \& B.Ed., Bishop’s University, 2017 \& 2018

A Major Research Paper

presented to Ryerson University

in partial fulfillment of the requirements for the degree of

\author{
Master of Arts \\ in the Program of \\ Immigration and Settlement Studies
}

Toronto, Ontario, Canada, 2019

(C) Micheline Chevrier 2019 


\section{AUTHOR'S DECLARATION FOR ELECTRONIC SUBMISSION OF A MAJOR RESEARCH PAPER (MRP)}

I hereby declare that I am the sole author of this Major Research Paper. This is a true copy of the MRP, including any required final revisions.

I authorize Ryerson University to lend this MRP to other institutions or individuals for the purpose of scholarly research.

I further authorize Ryerson University to reproduce this MRP by photocopying or by other means, in total or in part, at the request of other institutions or individuals for the purpose of scholarly research.

I understand that my MRP may be made electronically available to the public.

Micheline Chevrier 


\title{
THE IMPACT OF AN ACCENT: THE EXPERIENCES OF INTERNATIONAL COLLEGE STUDENTS FROM INDIA IN THE GREATER TORONTO AREA
}

\author{
(C) Micheline Chevrier 2019 \\ Master of Arts 2019 \\ Immigration and Settlement Studies \\ Ryerson University
}

\begin{abstract}
India is one of the world's largest sources of international students with 553,440 studying abroad globally, its Ministry of External Affairs estimated in late 2017 (Vanderklippe, 2019). Canada has become an increasingly attractive destination for this cohort of international students. With English as the dominant global language for commerce and politics, and the fact that more people now use English as a second language than a first language (Crystal, 2003), these speakers become uniquely positioned in an English-dominated environment such as Canada, due to their accents. This exploratory study investigates the experiences of Indian international students studying at colleges in the Greater Toronto Area ("GTA") in relation to speaking with a foreign accent. The primary data was collected through five interviews. This study is enlightened by Pierre Bourdieu's concept of capital, specifically linguistic capital, which is employed in order to make sense of and understand the participants' experiences across varying social fields.
\end{abstract}

Keywords: international students; Indian international students; college; Toronto; Canada; foreign accent; perceptions; experiences, cultural capital 


\section{Acknowledgements}

My sincere gratitude goes to Dr. Sutama Ghosh for not only inspiring my formulation of this MRP, but also for her insight, care and support throughout the entire process. Also, a special thank you to my second reader, Dr. Harald Bauder. My position as a research assistant was critical in enabling me to complete this undertaking. It is my hope that Dr. Ghosh will be able to use my analysis to inform her greater study on Indian international students studying in the GTA. 


\section{Table of Contents}

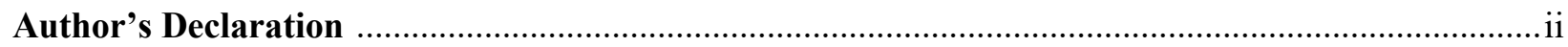

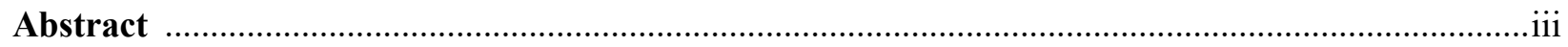

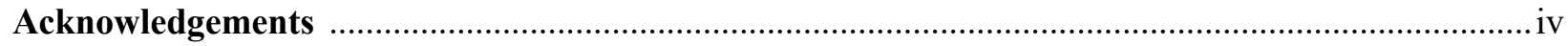

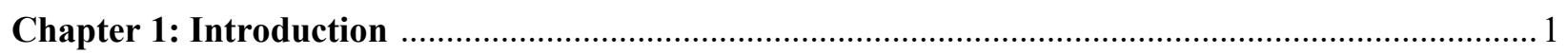

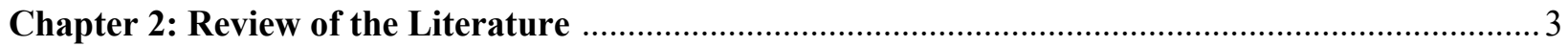

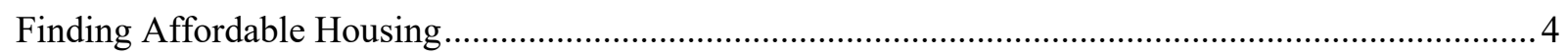

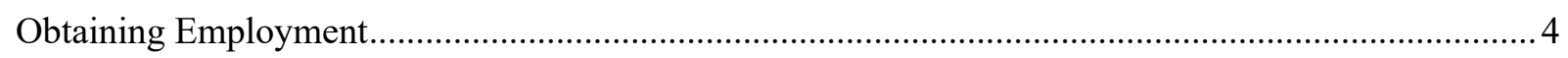

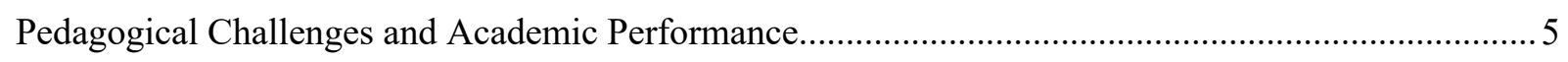

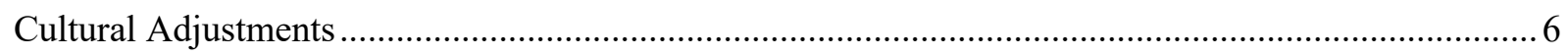

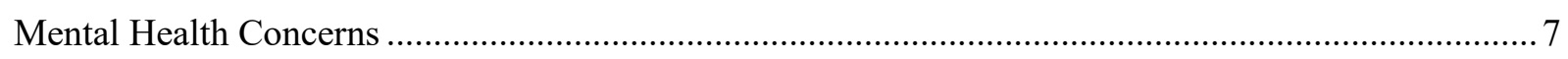

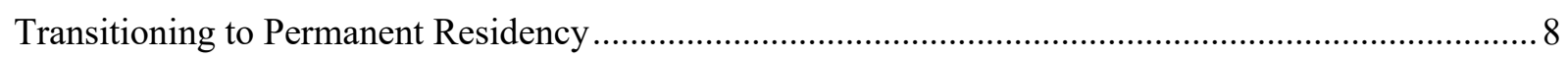

Language, Proficiency, Accent, and Associated Discriminatory Practices........................................ 9

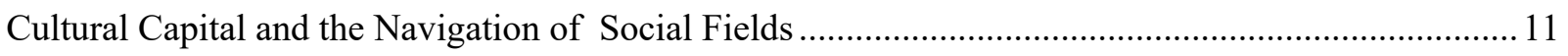

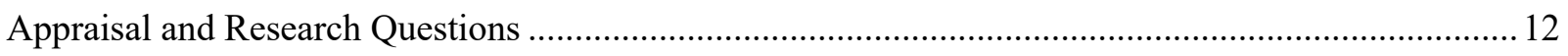

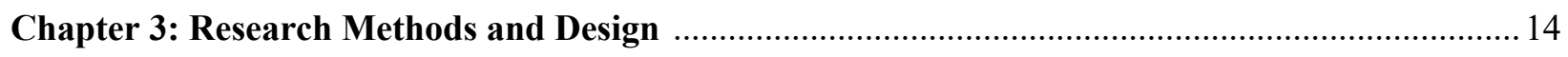

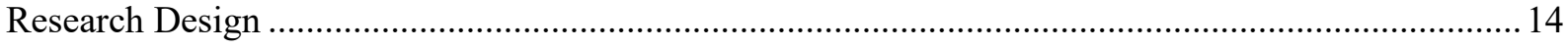

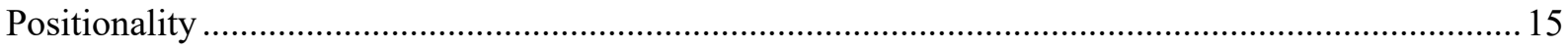

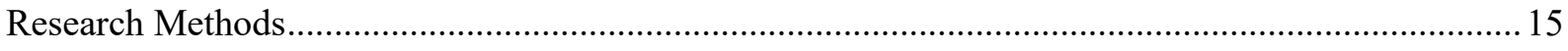

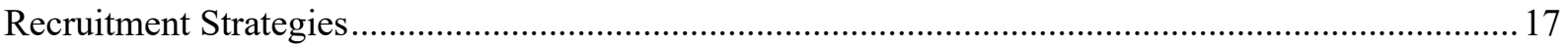

Method of Data Collection and Analysis..................................................................................... 18

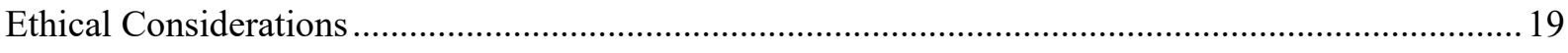

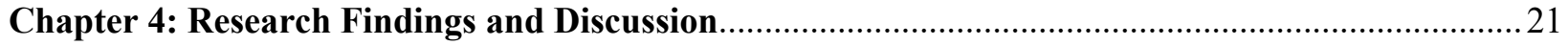

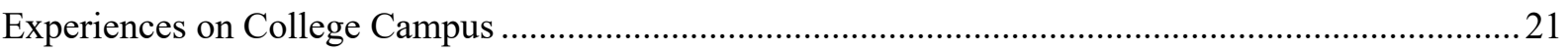

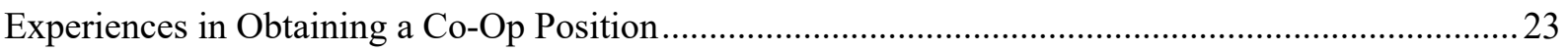

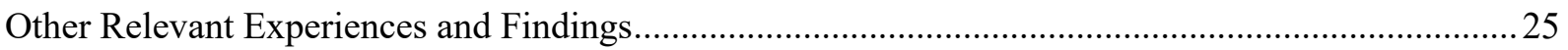

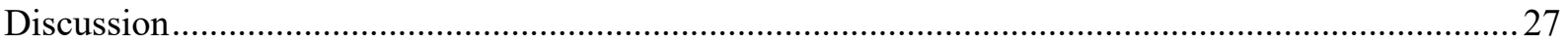

Chapter 5: Conclusion: Limitations of the Study and Future Research ............................................31

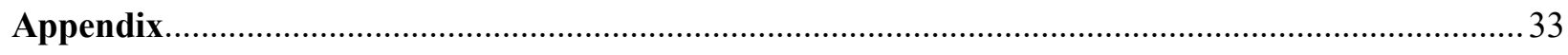

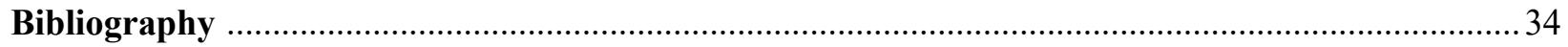




\section{Chapter 1}

\section{Introduction}

Canada is currently the third most popular destination country for international students ${ }^{1}$, behind only the United States of America and Great Britain (CBIE, 2018). In 2017, the total number of international students ("ISs") in Canada, accounting for all levels of study was 494,525 (CBIE, 2018). Additionally, the volume of international student ("IS") migration to Canada is on a steady rise. In 2018, for instance, there were more than 572, 000 of them in Canada (ICEF, 2019). Recent research has demonstrated that, the majority (65 percent of all ISs to Canada) come from five source countries: India, China, South Korea, France, and Vietnam (CBIE, 2018). Moreover, recent research suggests that the majority of ISs to Canada pursue undergraduate degrees and a significant portion (nearly 20\%) attend community colleges (Bozheva, 2018).

It is important to note that, the presence of ISs endows the Canadian post-secondary education sector with an additional source of revenue through the payment of high international tuition fees, living expenditures and labour contributions (Calder et al., 2016). A 2017 report for Global Affairs Canada estimated that in 2015 and 2016, total spending by ISs and their visitors reached \$28.3 billion (Vanderklippe, 2019). Undoubtedly, this has an immensely positive economic impact on the country.

Despite the increasing proportion of ISs to Canada, there remain several gaps in the available research. Presently, the research primarily concerns itself with graduate and postgraduate ISs to Canada. Moreover, an abundance of research been concerned with Asian, specifically Chinese, ISs. Thus, many other ethnic cohorts have been neglected, including Indian ISs at the college level who are also on the rise in Canada. Although language barrier is considered to be an important challenge for many ISs to Canada, there are no studies that are concerned with the problems faced by ISs related to their foreign accent.

Limited English language proficiency has the ability to impact many aspects of these students' lives and experiences on- or off-campus. According to the Canadian Human Rights Act, discrimination is an action or decision that leads a person or group to feel badly for reasons

\footnotetext{
${ }^{1}$ An international student is a person who ".. has left his or her country, or territory of origin, and moved to another country or territory with the singular objective of studying" (World Education News \& Reviews, 2009, p. 1).
} 
such as they race, age, religion, sexual orientation, marital status, etc. (Canadian Human Rights Commission, n.d). Discrimination based on accent is rooted in prejudiced listeners who discriminate against others based on the way they speak (Lippi-Green, 2012). Often an individual's perception of another's accent can influence the way they interact with or view that person. "In fact accent is just one of a number of characteristics, along with skin color, dress, or mannerisms, that may be used to identify someone as "foreign" or "different" and that can serve as an excuse for discriminatory treatment" (Munro, 2003, p. 39). This notion is applicable to immigrants to Canada in general, but also to ISs who often speak English as a second or third language with an inevitably different accent than the English "standard" in Canada.

The main objective of this study is to answer the following research questions: (1) What are Indian ISs' perceptions of the impact of their English accents on their college experiences in the GTA? (2) To what extent are Indian ISs' in the GTA aware of discrimination that is based on accent? These questions are important for exploring the impact of a foreign accent among Indian international college students in the GTA, and will fill a void in academia.

With discriminatory societal attitudes towards accents becoming normalized, especially through Western media i.e., television shows, South-Asian accents and characters are often highly racialized. It is through this study involving Indian ISs in the GTA, that there will be an opportunity for the details of these students' past and present experiences during their time on Canadian college campuses, with respect to their foreign accents, to be heard. Indian ISs make up the largest cohort of incoming students (ICEF, 2019), and contribute to innovation within the Canadian educational and cultural landscape; moreover, they are a vital building block for internationalization at Canadian institutions and within greater society (CBIE, 2018). It is, therefore, important to understand their experiences and how their accents may affect their lives. Without the insight of Indian international college students, IS services, communities, and college campus environments cannot be improved.

In the following chapter of this MRP, a review of the literature pertaining to ISs with a focus on language barriers and accents will be examined, as well as Pierre Bourdieu's theory of capital, with particular attention to cultural and linguistic forms of capital. The third chapter addresses the methodology used to administer this study. In the fourth chapter an analysis of the findings will be provided and developed. Finally, in the last chapter, the main conclusions of this study will be summarized with suggestions for avenues of future research. 


\section{Chapter 2}

\section{Review of the Literature}

This chapter begins by providing a brief overview of the state of knowledge about IS migration to Canada. For this review, I focused predominantly on the academic literature published in the past 30 years using specific key terms such as: 'international students in/to Canada', 'Indian international students', 'experiences/struggles/challenges of international students in Canada', 'academic/non-academic challenges of international students', 'international students in Canada and language/cultural barriers', 'international students and accents', and 'discrimination against international students'. Overall, my search revealed that current academic literature on ISs to Canada focusses mainly on the challenges encountered by this group of migrants. It is important to note here that, ISs are deemed temporary migrants in $\mathrm{Canada}^{2}$, and as a result they do not enjoy the same benefits as permanent residents or citizens. Being a temporary migrant means that they do not have access to universal health care, nor can they seek government housing, nor can they claim unemployment insurance.

It has been well documented that ISs to Canada struggle in diverse, yet interconnected ways:

(i) Finding affordable housing (Calder, 2016; Kovacs Burns et al., 2016)

(ii) Obtaining employment (Nunes \& Arthur, 2013; Yalnizyan \& Grisdale, 2016; Neatby, 2017)

(iii) Facing challenges with respect to pedagogy which affects their academic performances (Zhou \& Zhang, 2014; Akanwa, 2015; Hunter-Johnson, 2016)

(iv) Issues related to cultural adjustment (Penderson 1991; Reynolds \& Constantine, 2007; Wei et al., 2007)

(v) Mental health concerns (Bradley, 2000; Leong \& Chou, 2002; Yakunina et al., 2011, Forbes-Mewett \& Sawyer, 2016)

(vi) Transitioning to permanent residency (Moore, 2008)

\footnotetext{
${ }^{2}$ International students are defined as non-Canadian students who do not have "permanent resident" status and have had to obtain the authorization of the Canadian government in order to enter Canada with the intention of pursuing an education (Statistics Canada, 2010). The study permit identifies the level of study and the length of time that the individual may study in Canada.
} 
In the next few paragraphs, I will briefly present the state of knowledge on each of these barriers.

\section{(i) Finding Affordable Housing}

The issue of housing for ISs in Canada is complex. In both Calder (2016) and Kovacs Burns et al.'s (2014) studies, ISs reported difficulties with finding affordable and suitable housing. The latter study explores Canadian university students' housing security, students revealed that their housing situation affected not only their academics, but their mental and physical health as well. The study highlighted the unique challenges faced by ISs. For instance, the ISs felt that their post-secondary institution did a poor job of making off-campus housing information available to students. As one interviewee shared: "The rents in those residences [oncampus housing] is so high, it's untouchable" (p. 56). Other students spoke of their experiences with landlords; many of them had had their rights violated but were unaware of Canadian laws and regulations and therefore believed they had no say in their circumstances. ISs risk being driven into precarious situations due to the aforementioned problems. In addition, students in Calder's (2016) study described the indirect influences affecting their housing situation which included difficulties with language.

\section{(ii) Obtaining Employment}

ISs are paying exceptionally high fees towards their education in Canada. While the price of tuition varies across Canada, Toronto's colleges and universities charge ISs approximately three times more than domestic students (Yalnizyan \& Grisdale, 2016). Many ISs have no choice but to seek employment during their studies. While their program is in session, they may work up to 20 hours per school week and full-time during scheduled breaks in the academic calendar (Immigration and Citizenship, 2019). However, acquiring a position of employment is not guaranteed. Similarly, upon completion of their studies, obtaining work in their field in Canada remains problematic. It is first necessary to obtain a Post-Graduation Work Permit (PGWP) which is required for any IS who wants to stay and work in Canada upon completion of their studies; this is likely the easy part, overall.

According to Habib (2017), once ISs accrue the knowledge and skills through their Canadian education, they are unable to utilize them as they face difficulties in obtaining employment in Canada and as a result, return home to their country of origin. For instance, Yeswanth 
Manivannan, a former IS from India believes he is extremely lucky to have secured employment in Canada upon graduation as his friends did not find the opportunities they needed after graduation and had to return home. He said, "I do have a lot of friends who came here with the same dreams as me, excelling in whatever they were good at. They had to go back. That is definitely sad" (Neatby, 2017). Neither language nor accent are explicitly stated as a reason for return. Securing employment in one's field is no simple task, and much is related to employer discrimination. Existing studies describe how misunderstandings with employers' often stem from the common misconception that ISs are not proficient in English (Nunes \& Arthur, 2013). Essentially, what appears to be occurring is that a lack of citizenship status is perceived as an inhibiting factor for employers to hire ISs (Nunes \& Arthur, 2013).

\section{(iii) Pedagogical Challenges and Academic Performance}

The literature reports that limited English language proficiency may compromise ISs' academic performance (Lyken-Segosebe, 2017) and pedagogical challenges are present as well. Studies have documented that ISs face more challenges on campus than domestic students (Kuo \& Roysircar, 2004 taken from Zhou \& Zhang, 2014). Limited English language proficiency impacts many aspects of these students' lives on campus, specifically, in relation to academic performance and befriending native English speakers, particularly student colleagues, study partners, etc.

In Zhou and Zhang's (2014) study, a participant revealed that they were surprised by the amount of work they needed to complete for their courses on a weekly basis. An Indian participant in Zhou \& Zhang's (2014) study was surprised that he had to begin studying on the

first day of the semester in Canada, whereas in his home country, he only needed to study during the exam period.

Moreover, it ought to be considered that, "Learning academic literacy involves engaging in a range of academic social practices; this effort entails much more than learning to speak and write in a new language. Rather, gaining academic literacy involves negotiating various academic discourses in multiple circumstances" (Curry, 2004, p. 52). It is also necessary to consider the additional burden for ISs taking tests in a language and culture that differ from their background knowledge, thus making it even more difficult for them to achieve academically (Massie, 2003). 
Li et al., (2010) observed that, “...for those international students whose first language is not English, their proficiency in English plays a crucial role in successfully completing their studies in an English-speaking learning environment” (p. 4). For instance, ISs must adopt to new teaching styles and curriculum differences in their non-native language. Post-secondary institutions in Canada tend to place much more of an emphasis on class participation than do institutions in other countries (Rabia, 2016). Therefore, speaking English for classroom participation may be a challenge for those ISs who are from an educational system where reading skills were emphasized at the expense of conversational skills (Sawir, 2005 taken from Akanwa, 2015). Moreover, processing information, being able to fluently communicate thoughts with professors, deliver classroom presentations, finding group work partners and contributing to group assignments may be problematic for ISs with a lack of fluency in the English language (Hunter-Johnson, 2016).

\section{(iv) Cultural Adjustments}

Cultural adjustment and stress have long been considered significant issues affecting the experiences of ISs (Reynolds \& Constantine, 2007). Studies have shown that lower proficiency in English is often associated with higher acculturative stress (Prieto-Welch, 2016). Reynolds \& Constantine (2007) have said language barriers are a challenge associated with adapting to a foreign country. There are also the issues of unfamiliarity with the Canadian educational system, distance from family, cultural misunderstandings and/or cultural isolation (Yakunina et al., 2011). "Although international students come from widely diverse backgrounds, they are expected to 'adjust' [and acculturate] to a narrowly defined set of behaviours requiring them to learn their new and 'proper' roles very rapidly (Pedersen, 1991, p. 10). In order take on these new roles, ones' cultural identity may have to be left behind.

Research has shown that acculturative stress stemming from cultural differences and language barriers in ISs places them at a heightened risk for depression. For instance, Wei et al.'s (2007) study involving 189 Chinese ISs in the U.S revealed that acculturative stress stemming from language difficulties was a significant predictor of depression. 


\section{(v) Mental Health Concerns}

It is not unreasonable to expect that ISs, like domestic students, would encounter similar stress inducing occurrences upon entering and pursuing a post-secondary education. Such stress inducing occurrences include but are not limited to: anxiety related to the unknown, academic pressures, financial concerns, and feelings of isolation (Bradley, 2000). As a result, mental health issues may develop. However, ISs encounter additional unique pressures which may exacerbate the aforementioned stressors.

Ultimately, these additional layers of pressure have the potential to accumulate and add to ISs' experiences of stress and difficulties with adjustment, which may lead to poor mental health outcomes. According to Leong \& Chou (2002), it is estimated that $15 \%$ to $25 \%$ of all ISs are at risk of experiencing psychological and psychiatric problems.

A lack of English language proficiency is considered the greatest risk factor in the likelihood of developing mental health concerns among ISs. Higher English language proficiency makes it easier for ISs to navigate their new environment and interact with others, all which may contribute to better self-esteem and adjustment (Yeh \& Inose, 2003). Moreover, as Smiljanic (2017) puts it, better English-speaking skills may also make ISs feel less selfconscious about their language skills or accent, which in turn could make them more comfortable in interacting with others, thereby increasing their social support network (p. 199). Further, a student counsellor in Forbes-Mewett \& Sawyer's (2016) study explained that "If students struggle with English 'everything else suffers,' including their academic performance and their capacity to 'connect' with others" (p.668).

Early intervention is important when it comes to mental health issues in order to prevent matters from developing further. "Delaying intervention often meant increased severity of mental health problems, with students requiring more intensive intervention than would otherwise have been necessary" (Forbes-Mewett \& Sawyer, 2016, p. 671). It has been found that ISs are one of the most underserved groups in academic institutions, in part because they tend to underutilize counselling services (Mori, 2000). In fact, research indicates that ISs' usage rates of counselling centre services are lower than that of domestic students (Masuda et al., 2009). The reason for this is likely influenced by cultural backgrounds. For instance, in some cultures, disclosing that one has mental illness is considered to be shameful (Kung, 2004). A study specific to India reveals the level of sensitivity, attitudes towards mental health, and the level of stigma associated with it. 


\section{CHART 9 \\ Three broad segments}

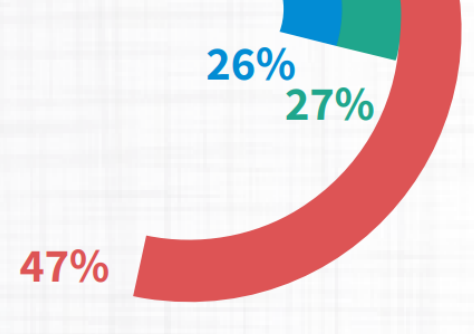

Segment 1 (27\%): Indicating Support for people perceived as having mental illness.

Segment 2 (47\%): Indicating higher judgement against people perceived as having mental illness.

Segment 3 (26\%): Indicating fear of people perceived as having mental illness.

* Base for cluster analysis was 3175 cases

(Padukone et al., 2018)

It is evidenced from the 3175 cases that many individuals view mental illness with apprehension and resistance, in India (Padukone et al., 2018). Such notion makes it difficult for people with mental health issues to seek out the support they need. ISs in Canada coming from a culture with a similar background, more specifically - perception of mental illness, are likely to be cautious or hesitant in seeking the help they may need.

In addition to the stigma, ISs may not feel comfortable speaking to a mental health practitioner who does not share their same ethnic background, primarily due to cultural and language differences (Lee et al., 2009). Moreover, institutional barriers such as a lack of knowledge of available resources and mental health services prevent ISs from receiving the professional help they may need (Bai, 2016). Taken in combination, such factors aid in understanding ISs' lack in seeking mental health assistance.

\section{(vi) Transitioning to Permanent Residency}

Regarding available research concerning ISs who have pursued permanent residency (PR) in Canada, solely one study, by Moore (2008) was found. It is worth mentioning that the study took place before the Government of Canada implemented the three-year Post-Graduation Work Permit that encourages ISs to remain in the country. It is also noteworthy that those 
applying for PR through the Express Entry Pool earn an additional 30 points in the Comprehensive Ranking System for completing post-secondary education in Canada (Immigration and Citizenship, 2017).

The participants in Moore's (2008) study sought PR during the final years of their programs. Although employment prospects were a major factor either pulling or pushing these students to stay or leave, a significant finding was the development of relationships and networks in Canada (Moore, 2008). The prominence of spoken English in Canada was an initial pull-factor for the participants in the study to choose an academic institution in the country due to the language's global access. However, language barriers were not found to be a challenge in obtaining PR, but rather the challenges were related to finances, a vague understanding of what dual citizenship would amount to, lengthy processing times, etc. What enabled the participants to manage these obstacles were the community support systems in Canada which had they had established over time, their persistence, and a willingness to pose questions which ensured them success (Moore, 2008).

\section{Language Proficiency, Accent, and Associated Discriminatory Practices:}

This literature review has revealed that although some of the challenges faced by ISs to Canada pertains to immigrants more generally, e.g., they face difficulty in finding affordable housing and obtaining adequate employment, there are also several unique challenges which are primarily related to their lack of proficiency in English. The extant literature indicates that language and communication barriers are among the most prevalent challenges faced by ISs in Canada - inevitably impacting these students' education and overall campus experience.

Language barriers have the ability to lead to discomfort in both academic and social contexts. As Hunter-Johnson, (2016) puts it, "This has a rippling impact on the self-confidence of international students and their ability to communicate and network effectively in the learning environment” (p. 167). Thus, ISs' confidence may begin to plummet and result in reinforcing the distance between them and domestic students.

Negative attitudes toward foreign-accented speech have led to discrimination against second language users in Canada (Munro, 2003). "A foreign accent refers to the breakthrough of native language phonology into the target language" (Lippi-Green, 2012, p. 46). According to

Derwing (2003), non-native English speakers in Canada experience 'accent discrimination' and 
are stereotyped by native speakers as less educated, less intelligent and less affluent. Some people regard any accent itself, as an undesirable trait (Munro, 2003), sometimes requiring additional effort to comprehend, while others may simply react in an ignorant manner. Gilakjani (2012) argues that unintelligible sounds may cause greater problems than speech with lexical or grammatical errors. Furthermore, "The impact of an accent does not appear to be restricted to communication, but also has been linked to stereotypical views that may lead to inaccurate judgement of students' intrinsic academic ability" (Eisenchlas \& Tsurutani, 2011 taken from Klieve et al., 2017, p. 3). Evidenced in several studies is the differential treatment towards individuals with a foreign accent. For instance, in Raisler's (1976) work, 730 undergraduate students rated an unseen speaker with a noticeable accent as less interesting, less convincing, and even less physically attractive than a native English speaker. Consider a more recent study by Creese (2011) which revealed many Sub-Saharan African immigrants to Canada expressed that their African accent was a barrier to equal treatment in Vancouver.

For many individuals, overcoming a foreign accent is an impossible task. It has been well established that the acquisition of a second language after early childhood inevitably results in speech that differs from that of native speakers (Munro, 2003). The time period in which acquiring a native sounding accent in a persons' non-native language is referred to as the critical period hypothesis, as derived by Eric Lenneberg (Bhatia, 2018). Lenneberg (1976) observed that foreign accents in a second language "cannot be over-come easily after puberty" (p. 176). The science behind the critical period hypothesis is described by Scovel (1969) and Asher and Garcia (1969) who state that it is the loss of neural plasticity that occurs with age in the brain which is likely responsible for the presence of a foreign accent. Thus, once an individual is past their critical period, the neurological or motor constraints that render native-like speech production become highly unlikely or impossible (Flege et al., 2006).

Discriminatory societal attitudes towards accents become normalized through the media. For instance, consider the depiction of characters with Indian accents on a television show such as The Simpsons, or The Big Bang Theory wherein the character Raj Koothrappali's humour is often rooted in his Indian accent. The South-Asian accents and characters are highly racialized. “The load of being an 'ESL person' seldom detaches from the body of the immigrant [...], this may be partially the reason why for many the label 'immigrant' continues to be part of their identity long after the legal status of the person has changed into the one of citizen" (Rockhill \& 
Tomic, 1992 taken from Tomic, 2013, p. 11). The Indian linguist, Braj Bihari Kachru, has claimed that based on his personal experience, "To have one's English labeled as Indian was an ego-cracking linguistic insult” (Kachru, 1992, p. 37 taken from Bhatia, 2018, p. 426). ISs, like other immigrants, are susceptible to discrimination in Canada based on their accents.

Furthermore, not all accents are perceived as being on equal grounds. Accent hierarchy is a concept used to explain the preference of certain accents over others based on racial and ethnic hierarchy (Kayaalp, 2016). Moreover, "Accent discrimination, in this regard, should be considered an outcome of the ethnic hierarchy in the host country as accents are always perceived in relation to minority youths' ethnic and racial backgrounds, including their bodies and skin tones" (Kayaalp, 2016, p. 133). Lippi-Green (1997) presents a similar stance: "It is not all foreign accents, but only accents linked to skin that isn't white, or which signals a third world homeland, that evokes such negative reactions (p. 238).

The notion of accent-based discrimination ${ }^{3}$ as a language barrier, stems primarily from the acceptance of a standard language (Lippi-Green, 1994). It can be defined as "a bias toward an abstracted, idealized, homogenous spoken language which is imposed from above [...], the most salient feature is the goal of suppression of variation of all kinds" (Lippi-Green, 1994, p. 166).

\section{Cultural Capital and the Navigation of Social Fields}

Language has the power to impact social behaviour as it has the ability to guide how people situate themselves in the matrices of belonging and the processes of othering (Siziba, 2014), which signify a measure of cultural capital (Bourdieu, 1986). Central to Bourdieu's theory is that various forms of capital: social, cultural, economic and symbolic, are interlinked and possibly exchangeable for one another. Cultural capital is the cultural knowledge that serves as currency that assists people in navigating culture, altering the experiences and opportunities available to one (Sociology Live, 2015). Furthermore, cultural capital takes on three forms: objectified (cultural goods - material objects which indicate social class), institutionalized (education credentials - the way society perceives or values them), and embodied (linguistic competence, cultural knowledge, mannerisms, etc. - residing within us) (Bourdieu, 1986).

\footnotetext{
${ }^{3}$ Discrimination is a broad term typically defined as treating a person or particular group of people in an unjust or prejudicial way typically on the grounds of race, age or sex (Canadian Human Rights Commission, n.d).
} 
Linguistic capital is a form of embodied capital which Bourdieu refers to as the acquired skills of speaking a dominant or "official" language as accorded by the specifications of those in power (Nawyn et al., 2012). An accent can represent a form of capital to the extent that it yields a benefit to the speaker who is so endowed (Lippi-Green, 1994), but only if it is considered a desirable accent. On the contrary, individuals lacking the desired or "dominant" accent in their speech risk being devalued and, in this regard, do not possess linguistic capital in that particular social field/context. Moreover, "In a person's speech habits - particularly those that are most unconscious, at any rate least amendable to conscious control, such as pronunciation [or accent] the memory of his or her origins, which may be otherwise abjured, is preserved and exposed" (Bourdieu, 1997, p. 659). In other words, accent and national origin cannot be separated. Furthermore, "When people reject an accent, they also reject the identity of the person speaking: his or her race, ethnic heritage, national origin, regional affiliation, or economic class" (Lippi-Green, 1994, p. 165). The effects of speaking with a devalued accent have several ramifications that hinder the accumulation of capital and the opportunities a person may be afforded which in turn, shape their entire being.

Due to the fact that college campus environments and the labor force are socially regulated, Pierre Bourdieu's ideas of capital and social field/context is applicable. "What makes Bourdieu's approach to capital particularly appealing to the study of migration is that forms of capital are inherently geographical" (Bauder, 2006, p. 37). This notion will assist us in understanding the shifting dynamic of capital, specifically linguistic capital, among Indian ISs as they navigate various transnational social fields/contexts. These social fields/contexts include: the movement from India to Canada, transitioning from English-medium or non-English medium schools to colleges in the GTA, etc. Moreover, social and cultural processes of distinction are relevant to Indian ISs experiences on-campus and off-campus. Language and accents are signs that carry cultural meanings and identify whether or not a person is a member in a given social group (Bauder, 2006), which ultimately affects their navigation through various social fields/contexts.

\section{Appraisal and Research Questions}

This literature review has highlighted that ISs in Canada struggle while adjusting to their destination country. Moreover, they encounter various challenges with finding housing, 
obtaining employment, transitioning to PR and cultural adjustment - any combination of which, can lead to mental health concerns and are exacerbated by language barriers. In addition, several academic studies and theories have been explored to provide background to these issues and reveal the nature of their vulnerabilities, including: Lenneberg's (1967) critical period hypothesis, accent hierarchy, and some cultures' perceptions of mental health issues which have a lingering and transnational impact on ISs in Canada. This review has further elaborated that the existing academic literature has several knowledge gaps which ought to be addressed in order to enable us to compare the experiences of speaking with a foreign accent among different cohorts of ISs in Canada. Firstly, most of the current research is on graduate students studying at Canadian universities. Therefore, the struggles of the undergraduate (including college) students remains unexplored. Secondly, most research has concentrated on Chinese students. Thus, little is known about other ethnic cohorts present on Canadian college campuses. 


\section{Chapter 3}

\section{Research Methods and Design}

\section{Research Design}

Indian ISs have a significant presence in post-secondary institutions across Canada. Additionally, by unofficial estimates, between 2004 and 2015, almost 70\% of all Indian ISs chose to attend colleges and universities in Ontario (The Canadian Magazine of Immigration, 2016). I became increasingly interested in studying Indian ISs experiences in the GTA due to my work contributions as a research assistant for Dr. Sutama Ghosh at Ryerson University. The project, titled, Exploring Resiliency Among International Students in the GTA: A Case Study of International Students from India Pursuing a Bachelors' Degree at the Community Colleges in the Greater Toronto Area, is a part of a larger study that is exploring migrant resiliency in Canadian cities.

I have both intrinsic and extrinsic reasons for undertaking this study. My intrinsic interest regarding the subject matter is because my partner came to Canada as an IS and speaks English as his second language, with an accent. He has shared with me that he felt he had experienced differential treatment in some restaurants in Canada due to his accent. Perhaps naively, this surprised me, as someone who has always been intrigued by accents and never perceived them as having negative connotations in Canadian society. The research findings may be relevant in providing insight into better understanding his experiences, as well as future work in my desired field of immigration. Extrinsically, I believe my position as a research assistant for Dr. Ghosh's project involving Indian ISs affords me an advantage in accessing the target cohort of students for obtaining data and exposure to requisite background knowledge.

Additionally, with a background in teaching English as a Second Language (ESL), linguistics has always been of interest. Through my work in teaching ESL, my employment as a refugee youth worker, and by virtue of being well-travelled, I have encountered many different accents. However, I had never considered the unique experiences a foreign accent may lead to in Canadian society, particularly on a college campus.

I also believe that without the insight of Indian international college students, international student services, communities, and college campus environments cannot be improved. For this reason, the research herein seeks to explore the impacts of speaking with a foreign accent and/or having a lack of English language proficiency on college campuses in the 
GTA, specifically, among students from the largest sending country of ISs to Canada — India (ICEF, 2019). This study is exploratory in nature and seeks to understand and make sense of the experiences of Indian international college students speaking English with an accent in the GTA.

\section{Positionality}

I am well aware of my position as an "outsider" to the study group. Prior to the commencement of the study I had several pre-conceived ideas about ISs from India. Initially, it was my belief that this cohort of ISs would not be proficient in English upon arrival to Canada. Furthermore, I was under the impression that these students had limited exposure to English in India, perhaps solely through secondary school English classes and American movies. Admittedly, I was not adequately knowledgeable of the extent nor impact of Britain's colonial past in India and the pervasive presence of English within the country, today. Indian ISs experience overt exposure to the English language and covert exposure to British cultural remnants in Indian society. Once in Canada, it is conceivable that, bearing in mind the literature pointing to language-based difficulties encountered by ISs, this exposure may give these students a relative advantage over some other cohorts of ISs as not many issues nor difficulties were reported being experienced on campus, by this study's subjects. The presumption that ISs from non-western nations will have poor English language skills is erroneous - that I now know.

\section{Research Methods}

In order to understand the effects of the self-perception of foreign-accented speech among Indian international college students in the GTA, primary research was conducted using a qualitative methodological approach. Creswell (2013) asserts that the main focus in qualitative research is on the process of research that "...flows from philosophical assumptions, to interpretive lens and on to the procedures involved in studying social or human problems" (p.44). Moreover, qualitative research includes: the participants' voices, reflection on behalf of the researcher, interpretation and description of the issue, and perhaps most importantly, provides a contribution to the literature which might bring about a call for change (Creswell, 2013). The primary data was gathered through telephone interviews with five participants. It is noteworthy that a Research and Ethics Board (REB) application was completed and approved prior to 
conducting the primary research. The data collection adhered to the REB policies and followed the guidelines outlined by the researcher in the REB application.

At the beginning of all interviews, information pertaining to the respondents' background was collected. The following demographic data was collected from all participants which assisted in the analysis of the findings:

\begin{tabular}{|c|c|c|c|c|c|c|}
\hline Pseudonym & Gender & Age & $\begin{array}{c}\text { Arrival in } \\
\text { Canada }\end{array}$ & $\begin{array}{l}\text { Level of } \\
\text { education } \\
\text { prior to } \\
\text { arrival in } \\
\text { Canada }\end{array}$ & $\begin{array}{c}\text { Had } \\
\text { previously } \\
\text { studied at an } \\
\text { English- } \\
\text { medium } \\
\text { school Y/N }\end{array}$ & $\begin{array}{l}\text { Current } \\
\text { studies }\end{array}$ \\
\hline Krish & Male & 23 & $\begin{array}{l}\text { December } \\
2018\end{array}$ & $\begin{array}{l}\text { Bachelor of } \\
\text { Information } \\
\text { Technology }\end{array}$ & Yes & $\begin{array}{c}\text { Information } \\
\text { Systems } \\
\text { Business } \\
\text { Analysis } \\
\text { Program }\end{array}$ \\
\hline Ankit & Male & 25 & $\begin{array}{l}\text { December } \\
2018\end{array}$ & $\begin{array}{l}\text { Bachelor of } \\
\text { Arts in } \\
\text { Hospitality } \\
\text { and Tourism }\end{array}$ & Yes & $\begin{array}{c}\text { Event } \\
\text { Management }\end{array}$ \\
\hline Rani & Female & 26 & January 2017 & $\begin{array}{c}\text { Bachelor of } \\
\text { Arts in } \\
\text { Marketing }\end{array}$ & Yes & $\begin{array}{c}\text { Marketing } \\
\text { Management }\end{array}$ \\
\hline Sagar & Male & 25 & $\begin{array}{l}\text { December } \\
2018\end{array}$ & $\begin{array}{l}\text { Bachelor of } \\
\text { Information } \\
\text { Technology }\end{array}$ & Yes & $\begin{array}{c}\text { Information } \\
\text { Systems } \\
\text { Business } \\
\text { Analysis } \\
\text { Program }\end{array}$ \\
\hline Anita & Female & 19 & April 2018 & $\begin{array}{l}\text { Bachelor of } \\
\text { Commerce }\end{array}$ & No & $\begin{array}{l}\text { General Arts } \\
\text { and Science }\end{array}$ \\
\hline
\end{tabular}

The ratio of male to female Indian participants was 3:2. The approximate age of participants was early to mid-20's which is typical of persons attending a college. All participants have been present in Canada for at least one academic school year, but none for more than three years. All of the participants had previously completed a bachelor's degree in India wherein two participants have obtained the same degree. Four of the five participants disclosed that they had in fact studied at an English-medium school in India. Finally, the participants are pursuing their current studies in differing fields from one another with the exception of two participants (the two that hold the same prior degree from India). 


\section{Recruitment Strategies}

Several recruitment strategies were utilized in order to ensure that there would be enough participants willing to take part in my study. Posters were hung throughout the GTA near colleges, Indian restaurants, bus stops, subway stations, and throughout Little India (a SouthAsian ethnic enclave) which is located along Gerrard Street East, Toronto. Current Indian ISs that have been studying at a college in the GTA for at least one year, is the demographic being targeted. All posters included the name and contact information of my supervisor, Dr. Ghosh, as the study fell under the umbrella of her work. Interested parties that were available to be interviewed either contacted Dr. Ghosh directly or got in touch with me and were then referred to her. Moreover, the posters included the advertisement of a \$25 gift card from Tim Hortons as an incentive for participation. Unfortunately, this strategy did not yield any participants.

It was thus necessary to amend the REB in order to include recruitment via social media, specifically Facebook, wherein I utilized my own networks. These networks consist of personal and professional acquaintances such as friends, relatives, former classmates, etc. I shared the same poster online as a Facebook post and asked my Facebook friends to share it. Although I do not have any friends that were eligible to participate in the study, these individuals may have ties to those who are eligible. Using personal networking as a starting point, my primary intention was not to have individuals within my immediate social group participate themselves, but rather, to activate their connections. The use of social networks to recruit participants is similar to the snowball sampling technique wherein subjects of a study refer the researcher to other potential participants, ultimately making the list of possible participants "grow like a rolling snowball" (Cohen \& Arieli, 2011, p. 424). Having been involved with people from all around the world, including India, through extra-curricular activities, sports, school, travel, etc., it is logical that the sampling "snowball" start with myself and "grows" as my own networks pass word of the study through their networks and so on, to eventually reach eligible participants.

Unfortunately, my reach had been overestimated and the aforementioned strategy was not as successful as had been hoped. What did generate plentiful interested participants was the use of Facebook to post the online poster directly into Toronto public college IS online groups. I believe the fact that interested participants could see my profile picture and put a face to the study ultimately made participation seem less daunting and more legitimate. Additionally, Dr. Ghosh recruited participants and being of Indian decent herself, was helpful to "...locate the 
appropriate population with a minimum amount of time, money and effort" (Cohen \& Arieli, 2011, p. 428).

For those that reached out to participate in the study, background check questions were posed in order to establish the eligibility of these individuals: 1) Are you an Indian IS? 2) Have you been studying for at least one academic school year at a college in the GTA? If the student answered yes to both questions, only then would they be asked about their availability in terms of setting a time to be interviewed. Consent forms were then emailed to participants in which they were asked to review the terms of their participation and to return the form, signed.

\section{Method of Data Collection and Analysis}

The initial intention of this study was to collect data through a 90 -minute focus group session with 8-10 participants. However, it quickly became evident that a focus group was not going to be feasible. All of the Indian ISs who called or emailed in response to the online posters, voiced that they would much prefer an interview rather than participate in a focus group session for two main reasons: comfort and convenience (most students were working multiple jobs).

It was thus necessary to adapt in order to gather the data. Although this change towards conducting interviews as opposed to a focus group session was perhaps more time consuming, in hindsight, it may have been of greater value. Certainly, based on the feedback received from interested participants, interviewees are less self-conscious in a one-to-one situation than they likely would have been in a focus group setting. Furthermore, interviews provide a useful way for researchers to study “... people’s understandings of the meanings in their lived world, describing their experiences and self-understanding, and clarifying and elaborating their own perspective on their lived world" (Kvale, 1996, p. 105).

The interview questions were topical in nature (i.e., semi-structured with contextual probing) which allowed for greater freedom and providing the opportunity to delve deeper when the discussion was headed in an unforeseen direction (see the appendix for the interview question guide). The semi-structured interview is flexible, allowing the interviewer to "...modify the style, pace and ordering of questions to evoke the fullest responses from the interviewee [...] it enables interviewees to provide responses in their own terms and in the way that they think and use language" (Qu \& Dumay, 2011, p. 246). Essentially, the semi-structured interview encourages participants to take the lead. This method proved itself valuable in understanding the 
interviewees' perceptions of their social world in relation to their accents. There were times when unscripted probes were voiced to further explore a specific area, while being wary not to compromise the authenticity of the responses. Often participants were prompted for elaboration to ensure clarity. In addition, the following demographic data of each participant was collected: age, gender, arrival date in Canada, level of education completed prior to arrival, current program of study, and whether the individual had previously studied at an English-medium school.

It is noteworthy that all the interviews, any necessary translations and transcriptions were performed by Dr. Ghosh. This was for several reasons. First, the required placement for this program led to an offer of full-time employment, which I accepted. This, however, limited my availability to conduct interviews at any time other than evenings or weekends, making it extremely difficult to coordinate with any of the participants' schedules. Second, participants would often switch from speaking in English to their native Indian language to provide more elaborate responses. Third, communicating and understanding becomes more difficult when people have different world views; Dr. Ghosh, who came from India to Canada herself as an IS decades ago has the background knowledge of Indian culture and speech mannerisms to reap the most of the interviews; in this regard, all the interviews were consistent and standardized. The interviews were all conducted over the telephone and recorded with the permission of the respondents and afterwards transcribed and analyzed. I took advantage of the opportunity to listen in, whenever possible.

In order to ensure that all analysis is trustworthy, several precautionary steps have been taken to demonstrate the study's validity and reliability. Because I have heard from Indian international college students, it is their perception of their English accent and how they experience the phenomena of a foreign accent on their college campus in the GTA that I am concerned with. All findings are based on the experiences that the participants face; furthermore, it is their account of their perception of the world and no one can tell them otherwise.

\section{Ethical Considerations}

Due to the nature of snowball sampling which entails social connections and already existing relationships between acquaintances, friends, family, etc., it would not be unreasonable to imagine there might arise some feelings of pressure to participate in the study. Thus, in order 
to mitigate this risk and potential negative influence, both Dr. Ghosh and I were very careful with communication style and approach. For instance, after an individual displayed interest in participating in the study, they would be asked to sign and return the consent form before an interview date was to be scheduled. If the individual did not respond once the consent form had been sent to them, communication was ceased.

In addition, all participants were asked to choose a pseudonym for themselves. In such instances, the pseudonyms were used throughout the entirety of the study including the transcribing of recordings and published results. Moreover, recordings of the interviews were not shared with any other party for any reason. Also, all of the recordings and information will be destroyed once the study is completed.

Apart from confidentiality and anonymity, the voluntary nature of participation was ensured and maintained at all times. Explicitly stated in the consent form was the acknowledgement that although the potential risks for participating in this study are very low, it is possible to feel somewhat frustrated while recalling certain incidents. In that case, participants were told they are most welcome to skip such questions, halt participation temporarily - e.g., take a break, come back and rejoin the interview when ready to speak again, or choose to completely stop participation entirely and have their data not used in the study. Moreover, participants were reminded of such at the beginning of their interview. 


\section{Chapter 4}

\section{Research Findings and Analysis}

According to Bourdieu (1991), cultural and more specifically, linguistic capital, cannot be understood separately from the broader socio-cultural context in which they are embedded. English is a dominant global language and more people now use English as a second language, as opposed to a first (Crystal, 2003). "Such speakers are commonly ascribed the status of "nonnative' speakers in English-dominant environments, and the asymmetrical relations that exist between these speakers and 'native' speakers have been documented" (Harrison, 2009, p. 1083). However, these issues have not been extensively explored nor discussed from the perspective of Indian international college students in the GTA - this section accomplishes precisely that.

In this section, the results from the interviews will be presented along with analysis providing insight into the research questions posed in this MRP. The findings of this study are divided into three categories: the experience on campus, the experience in obtaining a co-op position, and other relevant experiences and findings.

\section{The Experience on College Campus}

Having read the pertinent literature addressing the topic of the presence of discrimination based on accents and the language barriers experienced by ISs across post-secondary institutions, the findings from my interviews reveal contrasting experiences through the lens of Indian ISs studying at colleges in the GTA.

Four of the five participants, who are all attending colleges in the GTA, stated that they always felt understood by their peers and professors during class and that they did not experience any form of discrimination on campus. A participant by the name of Krish replied the following when asked if he ever felt misunderstood by his peers and/or professors because of his accent:

"In class? No no no. There are few Canadians in my class, but no one treats me differently because of my accent."

With one exception, similar answers were shared across the group of interviewees, demonstrating an overall positive experience on campus. In other words, for the majority of participants in this study, their accents did not hinder any of their interactions in the classroom nor throughout their campus - they did not feel that they had encountered any form of 
discrimination on campus. This directly contradicts the current body of literature concerning ISs in Canada.

The exceptional experience referred to above, was that of the participant Ankit and aligns with the available literature on international student experiences. When asked if he ever felt misunderstood by his peers and/or professors or felt discriminated against because of his accent he replied:

"Sometimes I was discriminated because the Indian tone is different. It is not easy to catch the words all together in one time."

It appeared as though he was excusing his Canadians peers for not understanding his accent and normalizing such occurrences. However, from the available literature and previous studies we know that a lack of attention to accented speakers is often the case. Thus, Ankit is likely doing himself a disservice by succumbing to the idea that the "Indian tone is different" and therefore "difficult to catch all the words". Also potentially embedded in the scenario is the recipient's lack of attention and/or attempt to discredit Ankit because of his accent in order to maintain the accent hierarchy and standard of English (done subconsciously). Ankit's response is also a reminder of the privileged position native of English speakers, who by virtue of birthright, acquire a valuable form of linguistic capital (Harrison, 2009).

Interestingly, both Ankit and another participant, Anita, revealed that they had difficulties understanding Canadians' accents, whether it be of their professor or peers. As explained by Anita:

"The professors are very good, but if I didn't't understand the assignment it's because I did not understand the accent. They will speak slowly when asked, but I have a lot of problems understanding the accent."

Similarly, Ankit is quoted:

"Also, because we are not spending time with them [Canadians], so it is difficult for us to understand them. There is a huge amount of groupism where Indians stay with Indians and Canadians with Canadians. They all stay together! I only interact with Indians and I don't like that, I want to learn more from them [Canadians]." 
There are two major take-aways from these responses. Firstly, prior English language exposure appears not to have prepared these participants to be receptive towards "Canadian English", a reflection of the fact that these Indian ISs would have been accustomed to British English accents. This form of embodied cultural capital is being devalued in the Canadian college social field/context through institutionalization that rewards receptiveness to Canadian English. In this regard, these Indian ISs are at a disadvantage because it is hindering their ability to thrive academically and socialize, thus limiting their ability to accrue other forms of capital.

Secondly, language use and accents may be the most overt marker of social identity in terms of how speakers from minority groups are perceived by members of the dominant language culture, which, in turn, implicates language in the process of social exclusion and discrimination (Lippi-Green, 2012). This assists in making sense of the divisiveness and groupism mentioned. Again, language or accent informs people of how to situate themselves in certain contexts. In this case, who they interact and socialize with.

Moreover, the Indian ISs' embodied cultural capital which to reiterate, is the know-how capacity that people bring with them when moving across different social spaces (Bourdieu 1991), led them to band together and socialize with others from the same background which ultimately led to the accumulation of social capital. In this sense, their embodied cultural capital is transnationally validated among other Indian ISs. In other words, being of Indian background and/or speaking the same native language is a form of cultural capital that appears to be exchanged for social capital and strengthens friendship among these students. Indian ISs “...engage in creating mechanisms of validation for their cultural capital" (Erel, 2010, p. 649).

\section{The Experience in Obtaining a Co-Op Position}

A major challenge that surfaced for a couple of the participants was in obtaining a co-op position. These participants were highly motivated to complete a co-op placement during their studies, in fact some hinting that they chose their program specifically for the co-op opportunity in order to gain Canadian work experience. Although the participants explained that the colleges were assisting them in securing a co-op position, the reach of the placement officers is limited and inevitably the decisions remain in the companies' hands as to whom they would like to have intern or to hire. The participant Krish, shared that the college he attended held a mandatory course throughout two semesters wherein students were equipped to apply for co-op positions. 
"In the first semester we had a course where we developed our portfolio, resume, etc., and in the second semester we also have the same things."

It appears as though the Indian ISs had been given some preparation skills to apply for their co-ops, and all of the participants had already obtained a bachelor's degree in India, signifying that they were, more or less, competitive candidates. It is worth mentioning here that "A Bourdieusian notion of cultural capital helps explain how educational and professional institutions exercise nationally-based protectionism by not recognizing qualifications acquired abroad, i.e institutionalized cultural capital” (Bauder, 2003 taken from Erel, 2010, p. 648). However, at the root of the lack of responses to co-op placement applications, although not explicitly stated, it may be the employer's presumption of an Indian accent that is hindering the participants' opportunities. Krish is quoted:

"Co-op is a huge challenge. We are applying to so many places, but no company responds to us. Out of 60 people, 48 people did not get a single response. It seems preferences are always given to Canadian citizens and Permanent Residents."

Sagar shared a similar sentiment:

"We are applying for co-ops now but not getting anything. I have applied for 100 positions. We need good references and I think also maybe because I am an international student."

The native speaker's language standards are taken to be the norm, and the non-native speaker may be ascribed inferior language abilities (Singh, 1998 taken from Harrison, 2009). In this regard, these participants recognized the communicative advantages that domestic students had over them in obtaining co-op positions.

It ought to be noted that language and accents are central to a person's identity. "Prejudiced listeners cannot hear what a person has to say, because accent, as a mirror of social identity and a 'litmus test for exclusion', is more important”' (Lippi-Green, 1994, p. 166). In this regard, these Indian ISs may not be given the opportunity to be heard because of the assumptions surrounding the accent they carry as a part of their identity. Bourdieu (1977) suggests that a person's ability to be heard is unequally structured for different speakers and depends on whether 
one is perceived to be a 'legitimate speaker'. The Indian ISs in this case are not being considered as legitimate speakers and thus, are being ignored, denied opportunity, and not seen as worthwhile of the employers' time, ultimately impacting their ability to be heard and accessing a co-op position.

\section{Other Relevant Experiences and Findings}

While analyzing the data from the interviews, several other findings arose which fell outside of the main research questions of this MRP. Nevertheless, they have important implications in their relationship to accent, identity and discrimination.

An interesting observation was that when the participants were asked if they ever felt discriminated against because of their accent, four of them responded yes and indicated that such events took place beyond their college campus, not solely in obtaining a co-op position, but in the labor force as well. Evidently, the accents and linguistic abilities of these ISs may also be subjected to scrutiny when they seek entrance to the general employment sector. A participant by the name of Rani sheds light onto his experience wherein he believes his accent may have played a negative role:

"At college, no that never happened. But yes, I felt a lot of discrimination when I went to look for a job. There they won't even talk very nicely to me. I am not sure if this was because of my accent or something else. Getting a job in the nice places was difficult, like Starbucks would not even take my resume."

Rani disclosed that he is now working at a grocery store. This alludes to the idea that he has been hired into a position that requires very little interaction with customers. "An adequate science of discourse must establish the laws which determine who may speak, to whom, and how [...] Among the most radical surest, and best hidden censorships are those which exclude certain individuals from communication (e.g., by not inviting them to places where people speak with authority, or by putting them in places without speech)" (Bourdieu, 1977, p. 648). In this manner, the participant seems to have been hired for a position in which speech is limited by the nature of the role. Herein, if it is indeed because of his accent, his cultural capital is thus being devalued in this social field/context. The participant Sagar shared a similar sentiment: 
"Finding a job in the nice places was difficult."

Although accent is not explicitly stated in the participants' response, previous literature has revealed that employers are favourably predisposed to hiring employees who are "like" them, and less disposed toward potential employees who are "unlike them" (Cutler, 1985 taken from Lippi-Green, 1994). The aforementioned participant eventually managed to get hired in a grocery store, however, he now works as an Uber Eats delivery person - a job with minimal interactions in English.

On another note, the participant Sat shared an incident that occurred beyond the realm of his college campus wherein he was discriminated against. The incident took place while on duty, working for the Toronto Transit Commission.

"This happened when I was doing TTC work. I was helping people with Presto cards and I was just standing normally then there was this man that was with his daughter and he was taking a bit of time, so I went to ask him, 'Do you need help?' He said, 'Do not come close to my daughter - just get away', and then abused me [verbally]."

Although accent is not explicitly stated in the participants' response, some research suggests that an accent has the power to amplify negative judgements made on the basis of a person's physical appearance when both physical and auditory cues are present (Holmes et al., 2001 taken from Harrison, 2009). Moreover, Bourdieu (1977) asserts, “...that people talk and talk to each other, are on 'speaking terms'. That those who speak regard those who listen as worthy to listen and those who listen regard those who speak as worthy to speak" (p. 648). In the aforementioned event, although Rani was merely performing his work duties with good intent, he was not perceived as worthy of being listened to. This illustrates the power dynamic at that is at play when speaking with an accent. Furthermore, racial undertones are present - accent and heritage are undeniably intertwined (Lippi-Green, 1994) and the participant's entire being has been undervalued.

When the participant Anita was asked if she had ever experienced discrimination based on her accent, she is responded:

"Yes - it has happened outside of the school." 
She did not want to go into further details. It can be speculated that she has likely had traumatic experiences in this regard, which is unfortunately, no longer surprising to hear based on the other participants' shared stories of their experiences with possible ties to accent discrimination taking place off-campus.

\section{Discussion}

ISs from India are unique in the sense that most are fluent in English upon their arrival in Canada, regardless if their accentuation differs from Canadian standard English. The historical context relating to this phenomenon ought to be considered. The presence of English in India dates back several centuries to European colonizers who arrived in India in the early 1600s and thereafter established trading posts in a number of cities under the control of The East India Company (The British Library Board, n.d). The combination of English language, Western education and British missionaries spreading Christianity, impacted Indian society. By the end of the eighteenth century, the British were able to bring India under their control. English was increasingly accepted as the language of government, of the social elite, and of the national press (The British Library Board, n.d). "It was from considerations of 'enlightened selfishness' that the British 'unified' India and imparted some sort of education to the 'swarthy' heathens of India" (Krishnaswamy \& Krishnaswamy, 2006, p. 73). In that sense, the English language was set to become the lingua franca for Indians of different regions and religions across the country, particularly among those belonging to the educated class. "On the one hand, English and English education became a unifying factor; on the other hand, they had a destructive effect on traditional Indian values and occupations" (Krishnaswamy \& Krishnaswamy, 2006, p. 75). It is noteworthy that such sentiment still resonates to this day.

When the country gained its independence in the year 1947, it was intended that English would gradually be phased out as the language of administration, however, in a country with multiple languages, there were no simple solutions to the problem of deciding which language should replace it (The British Library Board, n.d). As a result, The Constitution adopted in 1950, stipulated that English and Hindi would be used for the Union's official business for a period of fifteen years after which Hindi was intended to become the sole official language of the Union, however, there was strong opposition from Indian states wherein Hindi was not spoken (University of Ottawa, n.d). In 1963, the planned expiration of the fifteen-year period for English 
was cancelled and the Federal Parliament passed the Official Languages Act, which legally established Hindi and English as the languages used in Congress (University of Ottawa, n.d). This has had an effect on contracts, agreements, licences, permits and press related issues across India - all of which may be published in English (University of Ottawa, n.d).

The influences of colonialism continue to have an impact on the education and social climate in India today. English, indeed, remains engrained in Indian society. "The 2011 Census showed English is the primary language - mother tongue - of 256,000 people, the second language of 83 million people, and the third language of another 46 million people, making it the second-most widely spoken language after Hindi” (Rukmini, 2019). Speaking English also reflects a clear class dimension. English has continued to be the language of the elite and of governance in India (Aula, 2014). As Faust \& Nagar (2011) have said, “A class divided system of education has played a central role in molding the processes and patterns of uneven development and disenfranchisement in post-colonial India” (p. 2878). Furthermore, Bourdieu (1977) asserts, "The education system is a crucial object of struggle because it has a monopoly over the production of the mass of producers and consumers, and hence over the reproduction of the market on which the value of linguistic competence depends, in other words its capacity to function as linguistic capital” (p. 652). In most of urbanized India, there exists two main systems of education: English-medium and vernacular-medium and the former has been a ticket to vertical mobility in Indian society (Faust \& Nagar, 2011).

"English education, along with the changes in attitude, lifestyles, mannerisms, and aspirations that it brings, becomes a form of cultural capital that brings higher economic and cultural status for those who have access to English education and disenfranchise those who cannot gain access to it. It is their keen familiarity with the benefits bestowed by an English-medium education and with the economic marginalization and social indignity suffered by those who cannot speak fluent English, that compels middle class families to enroll their children in English-medium schools. The recognized role of English-medium schools is to give their students access to social prestige and well-paid jobs" (Faust \& Nagar, 2011, p. 2881).

English provides Indians with higher social status power and access to the job market; in these terms, it appears as though not all that much has changed since colonial rule. Moreover, the potential for accumulating cultural capital through English education cannot be ignored. "In a language learning context, language learners' investment of any accessible capital in a target 
language may have the potential to produce proficiency in this language, a profit that in return is convertible into various forms of capital” (Mu, 2014, p. 480). For those Indians that can gather the financial resources to study abroad, it casts them onto a trajectory of upward mobility. Not only is studying abroad a gateway to immigrate to Canada, but many Indians who wish to return home upon graduation will be considered more competitive by employers, in light of their international exposure (Sutarwala, 2019).

In the findings of the study on which this MRP is based, four of the five participants had attended an English-medium school in India, thus having an abundance of exposure to the English language prior to their arrival in Canada. Such knowledge of their previous studies in English is relevant to the findings as it helps us to make sense of the fact that the majority of participants had not experienced discrimination in relation to their accent or linguistic capabilities on campus or within their academic pursuits. It also explains why some had difficulty understanding the standard English in Canada because they had not previously been exposed to it, but rather British English accents.

It is paramount to acknowledge that cultural capital is not guaranteed nor accepted across all social fields/contexts. For instance, the linguistic capital the participants held while in India with respect to their grasp of the English language was a resource they used to gain access to studying abroad in Canada; however, it did not transfer transnationally beyond the field of the college campus once in Canada (i.e., in terms of obtaining a co-op position or gaining employment). In addition, “As more people seek to learn English in order to procure tertiary qualifications from Anglophone countries, the linguistic capital of native speakers automatically rises" (de Swann, 1998 taken from Harrison, 2009, p. 1096), thus an imbalance of power emerges, as exemplified through the off-campus experiences of the Indian ISs in this study. These students' English serves as a form of cultural and linguistic capital that can enhance professional mobility in the employment sector in India, however, the same cannot be said for within Canada as their Indian accents hinder this mobility.

In sum, the majority of the Indian ISs' in this study did not believe that their accents in English negatively impacted their interactions nor academics on their college campuses. Only one participant revealed that he felt discriminated on-campus due to his Indian accent. In fact, two of the participants actually had difficulties on campus not with the reception of their own accents, but rather in understanding the accents of their professors and/or peers. With regards to 
off-campus experiences, a couple of the participants believed that they faced discrimination in obtaining a co-op position and in the labor force, speculating that it was due to their accent.

When they did manage to find work, it was mostly in positions that do not require much use of English, i.e., non-communicative roles such as working in a grocery store. One exception to this was noted by a participant working for the TTC. Indeed, the Indian ISs in this study were aware that the discrimination they have encountered off campus has to do with their accents, although they were unaware to the extent. 


\section{Chapter 5}

\section{Conclusion}

The purpose of this final chapter is to expand on the limitations of this study, as well as possible avenues for future inquiry. However, it is first necessary to remind the reader of the main objectives of this research. As previously mentioned, the aim of this MRP was to answer the two following questions (1) What are Indian international students' perceptions of the impact of their English accents on their college experiences in the GTA? (2) To what extent are Indian international students in the GTA aware of discrimination that is based on accent? In fact, much more information has emerged than that which was originally set out to be discovered. This study is exploratory in nature and has sought to make sense of the experiences of Indian international college students speaking English with an accent in the GTA.

The effort herewith contributes to filling that void by investigating international students attending colleges in the GTA. Certainly, this research could be replicated using other cohorts of students, university campuses, public versus private colleges, different geographical regions in Canada etc., all of which could contribute to creating a pathway for comparative studies and enable a more thorough understanding of international student experiences in Canada. This work is important as a potential steppingstone for future authors to conduct and publish additional relevant research, leading to the identification of concrete strategies to support international students in overcoming their struggles resulting from language barriers. Moreover, the notion of accentuation differs from language proficiency and the former remains poorly investigated, particularly in relation to international students both on- and off-campus. By conscientiously conceiving of language barriers and accentuation as the root of challenges faced by international students, an awareness is created and is the first step towards provoking positive change.

The primary limitation of this analysis is the scope of its generalizability. This MRP provided insight into the experiences relating to accents of five Indian international students studying at a college in the GTA; thus, it cannot speak to the experiences of the hundreds of thousands of other international students in Canada. It is integral to the realistic interpretation of the data that the reader be mindful of the fact that this MRP is concerned with a small sample size and a particular ethnic cohort; further they hail from a colonized region that has provided significant English language exposure prior to arrival in Canada. 
The above limitations give way to a wide range of opportunities for future research. First, it provides an avenue for comparative studies, with the possibility of contrasting the experiences of this ethnic cohort on college campuses to the same group on university campuses, or between specific colleges, between private and publicly funded colleges, or across different provinces throughout Canada. Indeed, this would allow for a more complete picture of Indian international students with respect to their accents and experiences. Second, given the nature and design of this study, it is easily replicable among other ethnic cohorts of students arriving in Canada to study. It would be interesting to examine incoming students from countries untouched by European colonization (e.g., South Korea, Saudi Arabia), and comparing their experiences to the international students of formerly colonized, India. Historically speaking, each individual and ethnic body has their own cultural and linguistic baggage and it would be fascinating to contrast and compare experiences related to speaking with foreign accents. In so doing, one must wonder if and what accent hierarchies might be at play on Canadian post-secondary campuses and within greater society.

As illustrated throughout this MRP, international students contribute immensely within Canadian educational and cultural realms. Adequate English language proficiency for communication is vital for them as it plays an important role in their success and overall experience on- and off-campus. It has been demonstrated that most of their struggles stem from language barriers and/or accentuation, which has a rippling effect on all aspects of their lives'.

To conclude, a major take away from this MRP is a better sense of the impact of an Indian accent on college campuses for the participants in this study as well as their experience of hindered opportunities beyond the realm of the college campus. Ultimately, in order to gain a deeper understanding of the impact of a foreign accent in post-secondary institutions in Canada, more studies ought to be conducted with various cohorts of international students. In so doing, the new data would fill an information void and contribute to the amelioration of international student services, communities, and college campus environments. 


\section{Appendix \\ Interview Question Guide}

1. We all have accents. Do you feel that you are understood by your peers and professors during class or on campus?

2. Do you ever feel discriminated against because of your accent?

a. Probe/follow up: When did this incident occur?

b. Probe/follow up: How did this make you feel?

3. Can you please tell me whether you faced any challenges with respect to adjusting to the new pedagogical methods once you came here?

4. What are some of the general areas where you sought help?

a. Probe/follow-up: What about ESL?

b. Probe/follow-up: What about mathematics?

c. Probe/follow-up: What about general techniques?

5. Did you receive any assistance or help?

a. Probe/follow-up: Can you describe to me who helped you and how? 


\section{Bibliography}

Akanwa, E. (2015). International students in western developed countries: History, challenges, and prospects. Journal of International Students, 5(3), 271-284. Retrieved from https:// files.eric.ed.gov/fulltext/EJ1060054.pdf

Asher, J., \& Garcia, R. (1969). The optimal age to learn a foreign accent. The Modern Language Journal, 53, 3-17.

Aula, S. (2014, November 6). The Problem With The English Language In India. Forbes.

Retrieved from https:/www.forbes.com/sites/realspin/2014/11/06/the-problem-with-theenglish-language-in-india/\#5a69e5de403e

Bai, J. (2016). Perceived support as a predictor of acculturative stress among international students in the united states. Journal of International Students, 6(1), 93-106.

Bauder, H. (2003). "Brain Abuse” or the Devaluation of Immigrant Labour in Canada, Antipode 35(4): 699-717.

Bauder, H. (2006). Labor movement: How migration regulates labor markets. Oxford University Press.

Bhatia, T. K. (2018). Accent, intelligibility, mental health, and trauma. World Englishes, 37 , 421-431. Retrieved from https://onlinelibrary-wiley-com.ezproxy.lib.ryerson.ca/doi/pdf/ 10.1111/weng.12329

Bourdieu, P. (1977). The economics of linguistic exchanges. Social Science Information, 16(6), 645-668. doi:10.1177/053901847701600601

Bourdieu, P. (1986). The forms of capital. In: Richardson, J., Handbook of Theory and Research for the Sociology of Education. Westport, CT: Greenwood: 241-258.

Bozheva, A. (2018). Internationalization of Higher Education within Canada's Migration Management Framework: Supply Side of International Student Migration. Electronic Thesis and Dissertation Repository. 5850.

Bradley, G. (2000). Responding effectively to the mental health needs of international students. Higher Education, 39, 417-433.

Calder, M. J., Richter, S., Mao, Y., Burns, K. K., Mogale, R. S., \& Danko, M. (2016). International students attending Canadian universities: Their experiences with housing, finances, and other issues. The Canadian Journal of Higher Education, 46(2), 92. 
Canadian Human Rights Commission. (n.d.). What is discrimination?. Retrieved from https:// www.chrc-ccdp.gc.ca/eng/content/what-discrimination

CBIE (Canadian Bureau for International Education). (2018). International students in Canada. Retrieved from Canadian Bureau for International Education website: https://cbie.ca/ wpcontent/uploads/2018/09/International-Students-in-Canada-ENG.pdf

Cohen, N. \& Arieli, T. (2011). Field research in conflict environments: methodological challenges and snowball sampling. Journal of Peace Research 48(4), 423-435.

Creese, G. (2011). Erasing English Language Competency: African Migrants in Vancouver, Canada. International Migration and Integration 11.3: 295-313.

Creswell, J.W. (2013). Qualitative Inquiry \& Research Design: Choosing from five approaches. 3rd Edition. Los Angeles: Sage.

Crystal, D. (2003) English as a Global Language, 2nd edn, Cambridge, Cambridge University Press.

Curry, M. (2004). Academic literacy for English language learners. Community College Review, 32(2), 51-68. Retrieved from Academic Search Premier database.

Cutler, S (1985). A trait-based approach to national origin discrimination. Yale Law Journal 94:11164-81.

Derwing, T. (2003). "What do ESL students say about their accents." The Canadian Modern Language Review 59: 547-566. doi:10.3138/cmlr.59.4.547

De Swann, A. (1998). 'A political sociology of the world language system (2) : The unequal exchange of texts', Language Problems and Language Planning, 22(2), pp. 109-128

Education First (2012). EF English proficiency index 2012. Retrieved from www.ef.com/ epi.

Eisenchlas, S. A., \& Tsurutani, C. (2011). You sound attractive! Perceptions of accented English in a multilingual environment. Australian Review of Applied Linguistics, (34), 216-236. Retrieved from https://benjamins.com/catalog/aral.34.2.05eis/fulltext/aral. 34.2.05eis.pdf

Erel, U. (2010). Migrating cultural capital: Bourdieu in migration studies. Sociology, 44(4) 642-660. doi:10.1177/0038038038510369363 
Faust, D., \& Nagar, R. (2001). Politics of development in postcolonial india: English-medium education and social fracturing. Economic and Political Weekly, 36(30), 2878-2883.

Flege, J. E., Birdsong, D., Bialystok, E., Mack, M., Sung, H., \& Tsukada, K. (2006). Degree of foreign accent in English sentences produced by Korean children and adults. Journal of Phonetics, (34), 153-175.

Forbes-Mewett, H., \& Sawyer, A. (2016). International students and mental health. Journal of International Students, 6(3), 661-677. Retrieved from http://ezproxy.lib.ryerson.ca/login? url=https://search-proquestcom.ezproxy.lib.ryerson.ca/docview/1792214289? accountid $=13631$

Gilakjani, A. P. (2012). The significance of pronunciation in English language teaching. English Language Teaching, 5, 96. doi:10.5539/elt.v5n4p96

Habib, M. (2017). "New to Canada, Struggling to Find Work", The Globe and Mail. Retrieved from:https:/www.theglobeandmail.com/news/national/education/new-to-canadastruggling-to-findwork/article36660656/.

Hansen, H. R., Shneyderman, Y., McNamara, G. S., \& Grace, L. (2018). Assessing acculturative stress of international students at a U.S. community college. Journal of International Students, 8(1), 215-232. doi:10.5281/zenodo.1134293

Harrison, G. (2009). Language politics, linguistic capital and bilingual practitioners in social work. The British Journal of Social Work, 39(6), 1082-1100. doi:10.1093/bjsw/bcm 153

Holmes, K., Murachver, T. and Bayard, D. (2001) 'Accent, appearance, and ethnic stereotypes in New Zealand', New Zealand Journal of Psychology, 30(2), pp. 79-86.

Hunter-Johnson, Y. (2016). Against all odds: Socio-cultural influence on nontraditional international learners pursuing higher education in the United States (Doctoral dissertation). Retrieved from ERIC database.

ICEF Monitor. (2019, February 20). Canada's foreign student enrolment took another big jump in 2018. Retrieved from https://monitor.icef.com/2019/02/canadas-foreign-studentenrolment-took-another-big-jump-2018/

Immigration and Citizenship. (2017). Comprehensive ranking system (CRS) criteria - Express entry. Retrieved from Government of Canada website: https://www.canada.ca/en/ immigration-refugees-citizenship/services/immigrate-canada/express-entry/eligibility/ criteria-comprehensive-ranking-system/grid.html 
Immigration and Citizenship. (2019). As an international student, can I work in Canada without a work permit? Retrieved from Government of Canada website: http:/www.cic.gc.ca/ english/helpcentre/answer.asp?qnum $=496 \&$ top $=15$

International Education. (2017). Economic impact of international education in Canada - 2017 update. Retrieved from Global Affairs Canada - Roslyn Kunin \& Associates, Inc. website: https://www.international.gc.ca/education/report-rapport/impact-2017/ index.aspx?lang=eng

Kachru, B. B. (1992). The other tongue: English across cultures. Urbana, IL: University of Illinois Press.

Kayaalp, D. (2016). Living with an accent: a sociological analysis of linguistic strategies of immigrant youth in Canada. Journal of Youth Studies, 19(2), 133-148. Retrieved from https://journals-scholarsportal-info.ezproxy.lib.ryerson.ca/pdf13676261 v19i0002/133_lwaaassoiyic.xml

Klieve, H., Park, E., Tsurutani, C., \& Harte, W. (2017). International students' accented English - Communication difficulties and developed strategies. Congent Education, 1-15. Retrieved from https:/www.tandfonline.com/doi/pdf/10.1080/2331186X.2017.1314651? needAccess $=$ true

Kovacs Burns, K., Richter, M. S., Mao, Y., Mogale, S., \& Danko, M. (2014). Case study of a post-secondary institution and its response to student homelessness. International Journal of Case Studies, 3(9). 49-70. Retrieved from http://www.casestudiesjournal. com/Volume\%203\%20Issue\%209\%20Paper\%206.pdf

Kuo, B., \& Roysircar, G. (2004). An exploratory study of cross-cultural adaptation of adolescent Taiwanese unaccompanied sojourners in Canada. International Journal of Intercultural Relations, 30, 159-183.

Kvale, S. (1996). Interviews: An introduction to qualitative research interviewing. Sage Publications.

Lee, S., Juon, H., Martinez, G., Hsu, C., Robinson, E., Bawa, J., \& Ma, G. X. (2009). Model minority at risk: Expressed needs of mental health by Asian American young adults. Journal of Community Health: The Publication for Health Promotion and Disease Prevention, 34, 144152.

Lenneberg, E. (1967). Biological foundations of language. New York: Wiley. 
Leong, F.T.L., \& Chou, E.L. (2002). Counseling international students. In P.B. Pedersen, J.G. Draguns, W.J. Lonner, \& J.E. Trimble (Eds.), Counseling across cultures (5th ed.) (pp. 185-207). Thousand Oaks, CA: Sage.

Li, G., Chen, W., \& Duanmu, J. (2010). Determinants of international students' academic performance: A comparison between Chinese and other international students. Journal of Studies in International Education, 14(4), 389-405.

Lippi-Green, R. (1994). Accent, standard language ideology, and discriminatory pretext in the courts. Language in Society, 23(2), 163-198. Retrieved from http://rosinalippi.com/ weblog/wp-content/uploads/2012/11/Lippi-Green1994Accent-standard-languageideology-and-discriminatory-pretext-in-the-courts.pdf

Lippi-Green, R. (2012). English with an accent: Language, ideology and discrimination in the United States (2nd ed.). New York, NY: Routledge

Lyken-Segosebe, D. (2017). Acculturative stress and disengagement: Learning from the adjustment challenges faced by east asian international graduate students. International Journal of Higher Education, 6(6), 66. doi:10.5430/ijhe.v6n6p66

Massie, M. (2003). Standing on the promise of Brown and building a new civil rights movement: The student intervention in Grutter v. Bollinger. Albany Law Review, 66(2), 505. Retrieved from Academic Search Premier database.

Masuda, A., Hayes, S. C., Twohig, M. P., Lillis, J., Fletcher, L. B., \& Gloster, A. T. (2009). Comparing Japanese international students' and U.S. college students' mental health related stigmatizing attitudes. Journal of Multicultural Counseling and Development, 37, $178-189$.

Moore, H. (2008). From student to migrant: Migration narratives of international students in Canada. (Master's thesis). Retrieved from ProQuest Dissertations and Theses database. (MR45960).

Mori, S. C. (2000). Addressing the mental health concerns of international students. Journal of Counseling and Development, 78, 137-144. doi:10.1002/j.1556-6676.200.tb0271.x

Mu, G.M. (2014). Learning Chinese as a heritage language in Australia and beyond: The role of capital. Language and Education, 28(5). 477-492. doi:10.1080/09500782.2014.908905

Munro, M. J. (2003). A primer on accent discrimination in the Canadian context. TESL Canada Journal, 20(2), 38. doi:10.18806/tesl.v20i2.947 
Nawyn, S. J., Gjokaj, L., Agbényiga, D. L., \& Grace, B. (2012). Linguistic isolation, social capital, and immigrant belonging. Journal of Contemporary Ethnography, 41(3), 255-282. doi:10.1177/0891241611433623

Neatby, S. (2017, October 12). Most international students leaving Canada after graduation. Vancouver Sun [Vancouver]. Retrieved from https://vancouversun.com/feature/howinternational-students-are-filling-funding-shortfalls/chapter-4

Nunes, S. and Arthur, N. (2013). International students' experiences of integrating into the workforce. Journal of Employment Counselling, 50(1). doi: 10.1002/j. 2161-1920.2013.00023.x.

Padukone, D., Doraiswamy, M., \& Chandy, A. (2018). 5 charts that reveal how India sees mental health. Retrieved from World Economic Forum website: https:/www.weforum.org/ agenda/2018/04/5-charts-that-reveal-how-india-sees-mental-health/

Pederson, P.B. (1991). Counseling international students. The Counseling Psychologist, 19, $10-58$.

Qu, S. Q., \& Dumay, J. (2011). The qualitative research interview. Qualitative Research in Accounting and Management, 8(3), 238-264. doi:http://dx.doi.org.ezproxy.lib.ryerson.ca/ $10.1108 / 11766091111162070$

Prieto-Welch, S. L. (2016). International student mental health. New Directions for Student Services, 2016(156), 53-63. doi:10.1002/ss.20191

Rabia, H. M. A. (2016). Undergraduate arab international students' adjustment to U.S. universities. International Journal of Higher Education, 6(1), 131. doi:10.5430/ ijhe.v6n1p131

Raisler, L. (1976). Differential response to the same message delivered by native and foreign speakers. Foreign Language Annals, 9,256-259.

Reynolds, A. L., \& Constantine, M. G. (2007). Cultural adjustment difficulties and career development of international college students. Journal of Career Assessment, 15(3), 338-350. doi:10.1177/1069072707301218

Rockhill, K, and Tomic, P. (1992). Accessing ESL: An exploration into the effects of institutionalized racism and sexism in shaping the lives of Latin American immigrants and refugee women in metropolitan Toronto. Toronto: Ontario Ministry of Education. 
Rukmini, S. (2019, May 14). In India, who speaks in English, and where? Livemint [Chennai]. Retrieved from https://www.livemint.com/news/india/in-india-who-speaks-in-englishand-where-1557814101428.html

Sawir, E. (2005). Language difficulties of international students in Australia: The effects of prior learning experience. International Education Journal, 6(5), 567-580.

Scovel, T. (1969). Foreign accents, language acquisition, and cerebral dominance. Language Learning, 19, 245-253.

Singh, R. (ed) (1998). The Native Speaker: Multilingual Perspectives, Sage Publications, New Delhi.

Siziba, G. (2014). Language and identity negotiations: An analysis of the experiences of Zimbabwean migrants in Johannesburg, South Africa. Journal of African Cultural Studies, 26(2), 173-188. doi:10.1080/13696815.2013.860517

Smiljanic, I. (2017). The role of attachment, travel experiences and English proficiency in international students' acculturative stress and depressive symptoms. Journal of International Students, 7(2), 188-203. Retrieved from http://ezproxy.lib.ryerson.ca/login? url=https://search-proquest-com.ezproxy.lib.ryerson.ca/docview/1871392118 accountid $=13631$

Statistics Canada. (2010). Definition of "international students". Retrieved from Government of Canada website: https://www150.statcan.gc.ca/n1/pub/81-004-x/2010005/def/intlstudentetudiantetranger-eng.htm

Statistics Canada. (2018). Canadian postsecondary enrolments and graduates, 2016/2017. Retrieved from Government of Canada website: https://www150.statcan.gc.ca/n1/dailyquotidien/181128/cg-c001-eng.htm

Sociology Live. (2015, November 16). Cultural Capital [Video file]. Retrieved from https:// www.youtube.com/watch?v=5DBEYiBkgp8

Sutarwala, M. (2019, February 5). Top 5 reasons why Indian students study abroad [Blog post]. Retrieved from https://www.schoolapply.co.in/blog/posts/2017/october/top-5-reasonswhy-indian-students-choose-to-study-abroad/

The British Library Board. (n.d.). Asian English. Retrieved from http:// https://www.bl.uk/ learning/langlit/sounds/case-studies/minority-ethnic/asian/? fbclid=IwAR1DsPTZCZpgS2oiHRqbjP0nSje19P4Spp9DtK0zh_t8DShAubPYvpuSqa8 
The Canadian Magazine of Immigration. (2016, November 9). Indian Students in Canada. Retrieved July 20, 2019, from https:/canadaimmigrants.com/indian-students-canada/

Tomic, P. (2013). The colour of language: Accent, devaluation and resistance in Latin American immigrant lives in Canada. Project Muse, 45(1-2), 1-21. Retrieved from https://musejhuedu.ezproxy.lib.ryerson.ca/article/521077/pdf

University of Ottawa. (n.d.). India: Official languages act. Retrieved from https:// www.uottawa.ca/clmc/india-official-languages-act

Vanderklippe, N. (2019, March 1). In a shift on Canadian campuses driven by Trump policies, Indian students now outnumber Chinese. The Globe and Mail. Retrieved from https:// www.theglobeandmail.com/world/article-in-a-shift-on-canadian-campuses-driven-bytrump-policies-indian/

Wei, M., Heppner, P.P., Mallen, M. J., Ku, T.-Y., Liao, K. Y.-H \& Wu, T.-F. (2007). Acculturative stress, perfectionism, years in the United States, and depression among Chinese international students. Journal of Counselling Psychology, 54, 385-394.

World Education News \& Reviews. (2009, September 1). What defines an international student? A look behind the numbers. Retrieved from https://wenr.wes.org/2009/09/wenrseptember-2009-feature

Yakunina, E. S., Weigold, I. K., \& McCarthy, A. S. (2011). Group counseling with international students: Practical, ethical, and cultural considerations. Journal of College Student Psychotherapy, 25, 67-81.

Yalnizyan, A., Grisdale, C. (2016). "International Students Are an Asset We Need to Cultivate", The Star. Retrieved from: https:/www.thestar.com/opinion/commentary/2016/09/13/ international-students-are-an-asset-we-needto-cultivate.html.

Yeh, C.J., \& Inose, M. (2003). International students' reported English fluency, social support satisfaction, and social connectedness as predictors of acculturative stress. Counseling Psychology Quarterly, 16 (1), 15-28.

Zhou, G., Zhang, Z. (2014). "A Study of the First Year International Students at a Canadian University: Challenges and Experiences with Social Integration”, Canadian and International Education, 43(02), article 07, pp. 01-17. Retrieved from: https:// ir.lib.uwo.ca/cgi/viewcontent.cgi?article $=1288 \&$ context $=$ cie-eci. 